\title{
Training Future Teachers for School Work: Linguistic and Cultural Direction
}

\author{
Achaeva Marina Sergeevna \\ Kazan Federal University, \\ Elabuga Institute
}

\author{
Pospelova Nadezda Vladimirovna \\ Kazan Federal University, \\ Elabuga Institute
}

\begin{abstract}
Modern society is characterized by multidirectional, complex interacting processes of unification, diversification, globalization and multiculturalism. These processes cause significant changes in the education system. One of them is multicultural education. The relevance of research on various aspects of multicultural education in modern Russia has led to the emergence of multidimensional works. The multicultural orientation is reflected in the Federal educational standards of general education, in the standards of vocational education for bachelors and masters of pedagogical and psychological specialties. The objective of this work is to identify and theoretically substantiate the pedagogical conditions for the effectiveness of the formation of cultural pluralism in young professionals working in schools of a new type. The solution of the stated goal and verification of the proposed assumptions were provided by a set of complementary methods: retrospective, systemic, interviewing, included observation, conversation, testing, questioning, modeling and statistical method. The source of empirical data for this study was the questionnaire of young teachers of new type schools during the International School Teachers Festival in Tatarstan, Russian Federation, as well as the questionnaire of Alabuga International School teachers. As a result of the survey, the questionnaires were analyzed and problems encountered by young teachers were diagnosed. The authors of the article offer a number of recommendations for a more effective crosscultural education for future bachelors, young English language specialists. In their opinion, nursery rhymes, clerihews, which are "linguo-culturems", recreating the historical and cultural context, can serve as a successful material for intercultural education of future teachers. Here are some recommendations of the practical implementation of the nursery rhymes, clerihews in the training of the future teachers which are accompanied with illustrations and necessary notes. Special emphasis should be laid on the role of the pedagogical university in modern society, in the formation of competencies of future teachers and young specialists in the polyethnic region. Polycultural education promotes harmonization of relations between representatives of different civilizations and cultures. The main directions of multicultural education are bilingual education, multicultural education, accompanied by measures against ethnocentrism. The presence of a multicultural
\end{abstract}

environment allows stimulating the interest of learners in new knowledge and at the same time it offers different points of view on the world around us.

\section{Introduction.}

Modern society is characterized by multidirectional, complex interacting processes of unification, diversification, globalization and multiculturalism. These processes cause significant changes in the education system. One of such changes is multicultural education. The essence of multicultural education is the combination of several cultural traditions in the content, methods and organizational forms of education, leading to the recognition of students the cultural diversity as a social standard and personal value, to the appropriation of images of culture and of a human as a result of creative intercultural mutual enrichment [1],[2].

The relevance of research on various aspects of multicultural education in modern Russia has led to the emergence of multidimensional works of a generalizing nature on the history of the emergence and trends in the development of multicultural education in the world [3], [4], [5]; on the essence, content and principles of implementation of multicultural education [6], [7], [8], [9]; on modeling of multicultural educational space [3]; on training teachers for the implementation of the multicultural approach in the system of modern education; on organizational aspects of managing the development of multicultural education in a separate region. In recent years, domestic pedagogical theory has proposed increasing the effectiveness of education practice through the use of a polyparadigmatic approach [10].

\section{The main part}

The urgency of increasing the effectiveness of multicultural education was reflected in federal normative and legal acts: the National Doctrine of Education in the Russian Federation until 2025 (2000), the Concept of the National Educational Policy of the Russian Federation (2006), the Concept of Spiritual and Moral Development and Education of the Personality of a Russian Citizen (2009), the draft Concept of multicultural education in Russia (2010), etc. The multicultural orientation is reflected in the Federal educational standards of general education, in the 
standards of vocational education for bachelors and masters of pedagogical and psychological specialties.

The new requirements set forth in the Federal State Educational Standards presuppose not only the formation of educational and professional students' qualities, but also the formation of personal qualities and abilities: patriotism, love of the Motherland, respect for their people, their spiritual values and traditions, and at the same time respect and acceptance of other Cultures, the ability to achieve mutual understanding, constructive dialogue and the ability to live in a multicultural world.

Pioneers of the ideas of multicultural education, of course, are schools of a new type. In recent years, in order to optimize the educational process, such schools began to appear more often. For example, Alabuga International School ("Three Bears") is the first general educational institution of international level in the Republic of Tatarstan. The training is conducted under the British National Curriculum. Currently, Alabuga International School is actively working on the transition to the International Baccalaureate education program. The main goal of Alabuga International School is the development and education of inquisitive, erudite and caring young people who will contribute to the creation of a better and more peaceful future through intercultural understanding and respect in the everchanging modern world. There are such schools in Kazan.

The purpose of this work is to identify and theoretically substantiate the pedagogical conditions for the effectiveness of the formation of cultural pluralism in young professionals working in schools of a new type.

\section{Methods of Research}

The solution of the stated goal and verification of the proposed assumptions were provided by a set of complementary methods: retrospective, systemic, interviewing, included observation, conversation, testing, questioning, modeling, and statistical method.

The source of empirical data for this study was the questionnaire of young teachers of schools of a new type during the VII, VIII International School Teachers Festival in 2016, 2017 in Elabuga, Tatarstan, as well as teachers of the Alabuga International School ("Three Bears"). As a result of the survey (30 respondents), the questionnaires were analyzed, and problems encountered by young teachers were diagnosed. Such problems include:

- Organization of cooperation between students of different nationalities (in the "Three Bears" school children from England, Turkey, Bulgaria, Germany, etc. study). Difficulties in teaching a child who knows neither Russian, nor English, nor the Tatar language. $45 \%$ of the respondents;

- Lack of multicultural communication skills during the conduct of extra-curricular international events. Difficulties in organizing events related to the traditions of English-speaking countries days of St. Andrew, David, Patrick, etc. $30 \%$ of respondents;
- Relatively weak understanding of the functioning of schools of a new type, including international ones. $20 \%$ of the respondents;

- Methods of teaching a foreign language in a multilevel multicultural class in an elementary school. $70 \%$ of the respondents. In particular, the methodology of teaching mathematics, literature, speaking, writing, etc. Team teaching - there is no practice of joint teaching (joint lesson -2 teachers +2 classes). Knowledge gaps in children's foreign literature. $60 \%$ of the respondents.

- Not a clear understanding of the international system of assessing knowledge (38\%). For example, young specialists of this school are not sure about the parameters for determining the level of reading;

- Difficulties in communicating with parents of children (20\%). Many parents are foreign specialists of the free economic zone and the Kama industrial hub, i.e. carriers of a different culture;

- Insufficient awareness of the education system abroad. $15 \%$ of respondents;

- Lack of sufficient experience in the implementation of inter-subject relations, meta-subject knowledge in the process of organizing the lesson, etc.

\section{Conclusions and Recommendations}

Special emphasis should be laid on the role of the pedagogical university in modern society, in the formation of competencies of future teachers and young specialists in the polyethnic region. Polycultural education promotes harmonization of relations between representatives of different civilizations and cultures. The main directions of multicultural education are bilingual education, multicultural education, accompanied by measures against ethnocentrism. The presence of a multicultural environment allows stimulating the interest of learners in new knowledge and at the same time it offers different points of view on the world around us.

As recommendations for a more effective crosscultural education for future bachelors, young English language specialists, we would like to offer the following:

- Modeling of the multicultural educational process in the pedagogical systems of preschool and general education in schools of a new type;

- Media course, where educational and methodological materials are presented in the following areas: "Culture of different countries: customs and traditions"; "Culture and traditions of English-speaking countries"; "Elabuga is a multicultural town"; "The Republic of Tatarstan is a polyethnic region"; "Culture of the peoples of Russia"; "Ethnic holidays of different countries"; "The best museums / galleries of Russia and the world"; "Museums of Elabuga town";

- Advanced training courses on the basis of Elabuga branch of KFU (2017-2018). The program of courses is "Modern approaches to teaching English at school"; The organization of an online seminar "Intercultural Communication for teachers" within the framework of an advanced training course; 
- $\quad$ Training and retraining courses for educators in August 2017 during the International Festival of Teachers in Yelabuga Institute of KFU on the program "Training and professional support of young teachers in the context of the implementation of new federal education standards";

- Mentoring assistance, including training in the development of multicultural communication skills in the course of children's international events through museum, theatrical and tourist-local lore activities;

- Practical-oriented seminars on gaming technologies, on foresight methods and their effective use in the educational process; modeling of such events, for example, as excursions to "The City of Professions", "Earth Day", preparation of a cultural school diary (from the experience of the international school Kid Space in Kazan), implementation of "A week without walls" (from the experience of the international school "Three Bears"), staging fairy tales of the peoples of the world;

- Realization of the study of the experience of developed multicultural countries having traditions in multicultural education.

- In our opinion, nursery rhymes, clerihews, which are "linguo-culturems" [11], recreating the historical and cultural context, can serve as a successful material for intercultural education of future teachers. The word 'clerihew' came from the name of the author of this type of quatrain. Edmund Clerihew Bentley (1875-1956) an English journalist who invented a form of comic verse with four lines, now called a clerihew after his middle name. Clerihews are usually about wellknown people [12]. Some nursery rhymes as, for example, 'Hush-a-bye, Baby' are popular lullabies for children. Baby rhymes are often associated with games. For example, parents recite to their children 'This little pig went to market' and pull them by the toes, counting them to amuse; 'Each pig is a toe'; 'Humpty-Dumpty' is a riddle. Humpty-Dumpty is an oval-shaped figure who breaks after falling off a wall and cannot be mended-the answer to the riddle is ' $\mathrm{egg}$ '.

Many nursery rhymes contain in their memory (the cumulative function of the language) customs, traditions related to life in the village, with pets. Thus, the poem 'Baa, Baa Black Sheep' dates back to 1275 , it describes the events in England associated with the tax on wool. To verify the linguistic and cultural material, we used such solid lexicographic reference books as Eric Donald Hirsh 'Cultural literacy: What Every American Should Know'; Dictionary of Language and Culture, Longman Publishers; Oxford guide to American and British culture etc [13], [14], [15], [16], [12].

Here are some recommendations of the practical implementation of the nursery rhymes, clerihews in the training of the future teachers which are accompanied with illustrations and necessary notes.

Read the following clerihew. Try to read it with as much humour as possible.

John Stuart Mill

By a mighty effort of will

Overcame his natural bonhomie

And wrote "Principles of Political Economy".

\section{Notes and Commentary}

John Stuart Mill (1806-1873) an English philosopher whose ideals had a great influence on modern thought. His best-known works include "On Liberty" (1859), in which he argued that people should be free to do what they want if this does not harm others, and "Utilitarianism" (1863), in which he explained and supported the theory that actions are morally right if they lead to happiness.

\section{Exercises}

1. Match each word in column one, with a word or expression with the same or similar, meaning in column two

1) good-natured friendliness
a) effort

2) a serious attempt, a try

b) bonhomie

3) a scholar, thinker

c) philosopher

4) the freedom to go where you want, d) economy

do what you want, etc.

e) liberty

5) the operation of a country's money supply, trade and industry

Key: 1-b; 2-a; 3-c; 4-e; 5-d

2. Answer the following questions:

a) What is the clerihew about?

b) Where does each verse take place?

c) Underline the words in the poem which you consider to be rhythmical

d) Can you add anything else to what has been mentioned in the clerihew? (use the commentary)

3. Discuss in the pairs:

a) name other British philosophers

b) speak about any Russian philosophers

Look through the texts "George the First". "George the Third" and:

a) name the British kings and queens you know;

b) try to read it with as much feeling as possible;

c) say what every George of the royal dynasty is famous for.

George the First was always reckoned

Vile but viler George the Second;

And what mortal ever heard

Any good for George the Third?

George the Third

(Walter Landor)

Ought never to have occurred

One can only wonder

At so grotesque a blunder

(Walter Landor) 


\section{Notes and Commentary}

George I (1660-1727) king of Great Britain and Ireland (1714-1727). He was the first of the Hanoverian* kings and came to Britain from Germany on the death of Queen Ann. He was not popular in Britain, mainly because he did not learn to speak English. He did not try to follow English customs. He spoke to his ministers in French. But Parliament supported him because he was a Protestant.

George II (1660-1727) king of Great Britain and Ireland (1727-1760). He was the only son of George I and, like his father was not very interested in the government of Britain. He was, however, interested in the army and fought against the French. He was the last British king to lead his army into a battle.

George III (1738-1820) king of Great Britain and Ireland, was the grandson of George II and greatgrandson of George I. His reign (the longest of any kind of Great Britain) lasted from 1760 until his death in 1820 , when he was succeeded by his son, George IV.

George III was probably the least popular of all the Hanoverian Georges, though none of them was particularly likable George III certainly seems to have attracted his share of abuse, not least in respect of the American War of Independence ("George III lost America and then lost his wits", was a popular saying of the time). He suffered from mental illness for some periods of his life. In 1811 he became so ill that his son (George IV) was made Prince Regent.

George IV (1762-1830) acted as regent during his father's madness in 1811-1820 and after his death succeeded to the throne as George IV. He fell in love with a Roman Catholic widow and secretly married her in 1785 , but in 1795 he also married Princess Caroline of Brunswick in return for a settlement of his debts. He tried to dissolve this loveless marriage after his coronation. The problem required a parliamentary approval, but it was solved by Caroline's death in 1821 . George patronized the architect John Nash who developed Regent Street* and Regent's Park in London and designed the exotic Royal Pavilion at Brighton.

George V (1865-1936) king of Great Britain and Ireland, and the British Commonwealth from 1910 to 1936. In 1917 he stopped using German titles for his family, and the name of the royal house was changed to Windsor.

He became popular with the British people for supporting the British armed forces in World War I.

George VI (1894-1952) king of Great Britain and Northern Ireland (1910-1936). He was greatly admired by the British people during World War II for staying in London when it was being bombed by German aircraft. He was the last British king to be called 'emperor' and the first head of the Commonwealth of Nations. He married Lady Elizabeth Bowes-Lyon (the Queen Mother). Elizabeth II is her daughter.

This period is known as Georgian, especially in regard to architecture and furniture etc, though the term of Georgian is also applied to the reigns of any of the other Georges.
Hanoverian - of or supporting the line of English kings and queens which originally come from Hanover and ruled from 1714 to 1901 , German name Hannover.

Regent Street - named after the Prince Regent who in 1820 became George IV.

\section{Exercises}

1. Match each word in column one with a word or expression, with the same, or similar, meaning in column two.

1) strange or unnatural in a way

a) blunder

that is funny or frightening

2) a silly mistake

b) grotesque

3) a body of persons appointed or

elected as a law-makers of a country c) regent

4) a person who governs in place of a

king or ruling queen who is ill, absent, d) vile

or still a child

5) a very bad or unpleasant e) parliament

6) a member of any Christian church

which separated from the Roman f) protestant

Catholic church in the XVIth century

Key: 1-b, 2-a, 3-e, 4-c, 5-d, 6-f.

2. Answer the following questions:

a) What are these poems about?

b) What is your reaction to the third poem?

c) What is your attitude to the fourth clerihew?

d) What is the noun from occur?

e) What objectives go with (a) blunder?

f) What is the infinitive of reckoned?

3. Arrange the questions according to the logical order of the texts. Answer these questions.

1) Whose reign was the longest of any king of Great Britain?

2) What period is known as Georgian?

3) Who was the last British king to lead his men personally into a battle?

4) What kind of king was George I? Why did Parliament support him?

5) What George became popular with the British people?

6) Who was the last British emperor?

7) What king is remembered for having been insane?

8) Who was the first head of the Commonwealth of Nations? 
4. Learn the poems "George I", "George III" by heart.

5. Using your background information and different sources speak about any Russian popular (unpopular) tsar (tsarina).

\section{References}

[1] Hasan Arslan, Georgeta Rata, Multicultural education: from Theory to Practice, Cambridge Scholar Publishing, 2013.

[2] The International Encyclopedia of education, Pergamon Press, Oxford, 1994.

[3] Bessarabova, I.S. The current state and trends in the development of multicultural education in the United States, VSPU Publishing House, Volgograd "Peremena", 2008.

[4] Bessarabova, I.S. Goals, objectives and principles of multicultural education in Russia and the USA, "Modern science-intensive technologies", Volgograd, 2008, pp.97-99.

[5] Dzhurinsky, A.N. "Multicultural education: essence and development prospects", Pedagogy, Moscow, 2002, pp. 92-96.

[6] Danilyuk, A.Y. "Principles of Culturogenesis in Education”, Pedagogika, Moscow, 2008, pp. 3-8.

[7] Dmitriev, G.D. Multicultural Education, Public Education, Moscow, 1999.

[8] Palatkina, G.V. Multicultural education in a polyethnic region, Astrakhan State University Publishing House, Astrakhan, 2001.

[9] Suprunova, V.V., Sviridchenko Y.S. Polycultural Education: A Textbook for Student Institutions, "Academy" Publishing Center, Moscow, 2013.

[10] Matis, V.I. "Poliparadigmal approach as a methodological basis for creating a modern school", Siberian Pedagogical Journal, Novosibirsk, 2009, pp. 54-64.

[11] Vorobjev, V Lingvoculturology, Russian University of People's Friendship publishing house, Moscow, 2006, http://www.twirpx.com (15 October 2016).

[12] Longman Dictionary of English Language \& Culture, Longman Publishers, London, 2000.

[13] Oxford Guide to British and American Culture /ed. by Jonathan Crowther, Oxford University Press, Oxford, 2000.

[14] Oxford Guide to British and American Culture /ed. by Jonathan Crowther, Oxford University Press Oxford, Oxford, 2005.

[15] Hirsch E. and Joseph J., The Dictionary of Cultural Literacy: What Every American Needs to Know, 1988.

[16] Longman Dictionary of English Language \& Culture, Longman Publishers, London, 1994. 